\title{
Orígenes del cervantismo: el descubrimiento de la «patria» de Cervantes y las polémicas lingüístico- literarias de la época*
}

\author{
Miguel Ángel Perdomo Batista**
}

\begin{abstract}
Resumen
La polémica sobre la «patria» de Cervantes y sobre su descubridor arranca en el siglo XVIII y llega hasta nuestros días. Tradicionalmente, se ha atribuido el descubrimiento al P. Sarmiento y a Juan de Iriarte, pero en las últimas décadas parece haberse modificado esta opinión en beneficio exclusivo del benedictino. Aportaremos alguna prueba que pone en duda esta última idea y analizaremos la cuestión en el contexto en el que debe ser examinada, el de las polémicas lingüístico-literarias de la época y los orígenes del cervantismo.
\end{abstract}

Palabras clave: Juan de Iriarte; patria de Cervantes; siglo XVIII; polémicas.

Title: Origins of Cervantism: the discovery of Cervantes' homeland and the linguisticliterary controversies of the time

\begin{abstract}
The controversy over Cervantes' "homeland" and its discoverer began in the 18th century and continues to the present day. The discovery has traditionally been attributed to P. Sarmiento and Juan de Iriarte, but in recent decades this opinion seems to have changed for the exclusive benefit of the Benedictine. We will provide some proof that calls this last idea into question and we will analyse the question in the context that must be examined, that of the linguistic-literary polemics of the time and the origins of Cervantism.
\end{abstract}

* Agradezco encarecidamente a la Comunidad de PP. Trinitarios de Madrid, y en particular al P. Emiliano Tiburcio Moreno, que me facilitara copia del texto publicado por el padre Antonino de la Asunción en la Revista Trinitaria, 2 (1896-1897).

** Universidad de Las Palmas de Gran Canaria. miguel.perdomo@ulpgc.es / ORCID iD: https:// orcid.org/0000-0002-5019-2368. 
Keywords: Juan de Iriarte; Homeland of Cervantes; 18th Century; Controversies.

\section{Cómo citar este artículo / Citation}

Perdomo-Batista, Miguel Ángel (2019). «Orígenes del cervantismo: el descubrimiento de la 'patria' de Cervantes y las polémicas lingüístico-literarias de la época», Anales Cervantinos. 51, pp. 251-276, https://doi.org/10.3989/anacervantinos.2019.012.

\section{INTRODUCCIÓN}

Todo lo relacionado con la biografía de Cervantes suscita un enorme interés que en nuestro tiempo trasciende a los medios de comunicación, como puede comprobarse, por ejemplo, con el proceso de búsqueda de sus restos en el convento de las Trinitarias Descalzas de San Ildefonso entre 2014 y 2015, oportuna y ampliamente documentado por el diario $A B C$ con varios reportajes ${ }^{1}$. Tal es el caso también de la discusión sobre el lugar de nacimiento del escritor, origen de una larguísima y enmarañada polémica que surgió en la primera mitad del siglo XVIII y que alcanza hasta nuestros días, como se advierte en la polémica que en 2017 enfrentó al Ayuntamiento de Alcázar de San Juan con la Red de Ciudades Cervantinas (eldiario.es, 14-11-2017). Son muchos los lugares propuestos: Alcalá, Madrid, Sevilla, Alcázar de San Juan, Lucena, Esquivias, Consuegra, Toledo, Herencia, Madridejos, Arganda del Rey, Cervantes (Zamora) ${ }^{2}$. Y a tan dilatada lista habría que añadir el nombre de Sanabria, comarca señalada por César Brandiz (2005). No obstante, debe advertirse que la mayoría de los cervantistas consideran Alcalá como la verdadera patria de Cervantes, y que las demás candidaturas son meras conjeturas o carecen de una base documental que las sostenga.

En realidad, la polémica sobre el lugar de nacimiento de Cervantes comprende otra, también larga e intrincada: la discusión sobre su descubridor, que atañe a algunos de los personajes más relevantes del siglo XVIII, y que ha sido estudiada hace no muchos años por Santos Puerto y Santos Vega (2011). Esta segunda cuestión es la que nos proponemos examinar, aunque nuestro análisis quizá contribuya a iluminar también la otra. En el siglo XVIII, comúnmente se aceptó que el descubridor del lugar de nacimiento de Cervantes había sido el bibliotecario Juan de Iriarte a instancias del P. Sarmiento, y que a ambos correspondía el mérito; en nuestros días, prevalece la opinión de que el descubrimiento se debió exclusivamente a Sarmiento, y así lo sostienen, entre otros, Pensado (1987), Rey Hazas y Muñoz Sánchez (2006), Santos Puerto y Santos

1. Puede verse también Fraguas (2014), y está detalladamente explicado en Lucía Megías (2016).

2. Pueden verse las dificultades y discusiones sobre los datos biográficos de Cervantes, y en particular sobre su lugar de nacimiento, en una conferencia de Mariano Lizcano Zarceño (2006). 
Vega $(2011)^{3}$. Aportaremos alguna prueba que pone en duda esta última opinión y analizaremos la cuestión en el contexto en el que debe ser examinada, el de las polémicas lingüístico-literarias de la época, porque quizá contribuyan a explicar lo que pudo suceder. En este sentido, conviene olvidar lo que sabemos hoy y hacer un esfuerzo de imaginación para comprender lo que pudo haber ocurrido. Por lo demás, la discusión sobre la "patria" de Cervantes y sobre su descubridor no debe ser explorada sin tener en cuenta otro aspecto fundamental que nos ayuda a entender la relevancia que históricamente ha ido adquiriendo la cuestión: los orígenes del cervantismo.

\section{ORÍGENES DEL CERVANTISMO}

Para Rey y Muñoz (2006: 48), el origen del cervantismo hay que situarlo en la Vida de Cervantes que Mayans redactó por encargo de Lord Carteret para incluirla al frente de la edición del Quijote 4 . Una segunda edición de la biografía también fue publicada como suelto en Madrid en 1750. Como se sabe, Carteret pretendía obsequiar a la reina Carolina para afianzar su posición política contrarrestando la influencia negativa que el primer ministro, Robert Walpole, ejercía sobre ella (Álvarez Faedo 2007). Se trata de la primera edición monumental del Quijote y de la primera que incluye su retrato. Como señalan Rey y Muñoz (2006: 29-30), el modelo de Carteret (vida de Cervantes, texto del Quijote cotejado y aderezado con láminas) se convertiría en el patrón para las ediciones posteriores. Mayans dedicó las 5 primeras páginas de la biografía a la cuestión del lugar de nacimiento de Cervantes, y concluía que el escritor había nacido en Madrid (p. 5).

Pero aunque fuera Mayans el que encendiera la llama del cervantismo, no debe olvidarse su otro hito fundacional: la edición del Quijote de John Bowle en 1781, que fue precedida de su biografía de Cervantes (publicada en 1781 en Gentleman's Magazine, LI, 22-245) y de su Letter to the Rev. Dr. Percy... $(1777)^{6}$. No es gratuito que se haya considerado a Bowle el primer hispanis-

3. Lucía Megías (2016: 89-90) señala que la transcripción de la partida de Alcalá fue remitida por el párroco de Santa María la Mayor a Pingarrón, que la comunicó a Mayans e Iriarte, pero no documenta ni argumenta estas afirmaciones.

4. Según José César Álvarez (2011: 71), Mayans también recibió el encargo de Ensenada de preparar una magna edición cervantina, pero el proyecto no se llevó a cabo. No obstante, en su preparación, Martínez Pingarrón escribió a Mayans diciéndole que iba a solicitar la partida bautismal de Cervantes al abad de San Justo en Alcalá de Henares. Hay una referencia al proyecto de Ensenada (a través de una referencia a su colaborador Agustín de Ordeñana) en Fernández de Navarrete (1819: 205-206). Según este, la edición madrileña propuesta por Ensenada serviría de emulación a la edición londinense de Carteret (1755).

5. Pueden verse también otras cartas referidas a Cervantes: Gentleman's Magazine, 54 (1784): 565-566; 55 (1785): 414.

6. Aunque no suele citarse en este sentido, creo que la Noticia sobre la verdadera patria (Alcalá) de Él Miguel de Cervantes, redactada por Sarmiento en 1761, es un importante monumento fundacional del cervantismo. 
ta, pues naturalmente el cervantismo es también hecho medular del hispanismo. El cervantismo es un fenómeno amplio y múltiple (editorial ${ }^{7}$, cultural, educativo, social, político y, naturalmente, económico) y quizá sería mejor decir que hay varios cervantismos, o, mejor, diferentes tiempos del cervantismo en distintos contextos, y que al menos habría que distinguir el cervantismo hispano del foráneo.

Como se sabe, la Vida de Mayans contiene algunas notas biográficas de Cervantes y una serie de valoraciones sobre el Quijote. Y es que, como señala Canavaggio (2005: 11), hay dos caminos para acercarse a la vida de Cervantes: los documentos biográficos y la obra. Pero, como han señalado agudamente Rey y Muñoz (2006: 34), la Vida de Cervantes de Mayans no es tal, sino más bien un concepto $^{8}$. Creo que podría interpretarse el cervantismo, o al menos una parte de este, como un trasunto metaficcional o metaliterario en el que se interpela al delicado límite entre realidad y ficción o a las complejas relaciones entre ambas y entre vida y literatura. El cervantismo aparece entonces como una apelación metaficcional a la biografía de Cervantes, establecida ya por el propio autor en el texto. En este sentido, quizá no fuera excesivo formular el cervantismo como una creación cervantina. Lo cierto es que durante el siglo XVIII, y aún después, la biografía cervantina se convierte en una suerte de referente metaliterario y metaficcional.

Por eso, y frente a la interpretación del nacimiento del cervantismo como un proceso que se produce a lo largo del siglo a partir de las interpretaciones trascendentes del Quijote (Cuevas Cervera 2009: 352), creo que la cuestión fundamental es la naturaleza polémica de la obra, que plantea la pregunta que inaugura la modernidad: qué es lo real, qué es lo racional. Pues naturalmente, la idea de racionalidad tiene que ver con la idea sobre la naturaleza y los fines de la existencia humana, según cierta filosofía de la historia que caracteriza precisamente la mentalidad ilustrada. En este sentido, el cervantismo que se inicia con Mayans tal vez podría interpretarse como una combinación de los ideales de la modernidad con la tradición humanista. No en vano, Forner veía a Cervantes como un continuador de Vives en su crítica de los libros de caballería (Rey y Muñoz 2006: 472).

\section{LAS POLÉMICAS}

Si la búsqueda y localización de documentos sobre la vida de Cervantes en el siglo XVIII está plagada de polémicas, ¿qué nos dicen estas polémicas?

7. El Quijote como fenómeno editorial en el siglo XVIII ha sido estudiado en varios trabajos por Enrique Rodríguez Cepeda (1988).

8. Fue Vicente de los Ríos (1780) el primero en aprovechar los documentos biográficos que se habían ido descubriendo a lo largo del siglo. Rey y Muñoz (2006: 56) señalan que lo más importante del texto de Ríos -la monografía más importante e influyente sobre el Quijote en el siglo XVIII- es, sin embargo, su análisis del Quijote, que se asienta sobre las principales ideas de Mayans. 
Como se ha señalado, parece oportuno examinar la discusión sobre la patria de Cervantes -y sobre su descubridor- en relación con las polémicas de la época, que le sirven de contexto 9 . Aunque, para ser operativos, vamos a referirnos solo a las polémicas directamente relacionadas o a aquellas que sucedieron en torno a la fecha en que se produjo el descubrimiento de la partida de nacimiento de Cervantes en Alcalá. En tal sentido, habría que distinguir las polémicas de carácter estrictamente literario de aquellas otras que tienen un carácter más personal, aunque debemos tenerlas en cuenta todas.

Empezaremos por las discusiones que en la segunda década del siglo mantuvo Luis Salazar de Castro con la Real Academia. La cuestión ha sido estudiada en varios trabajos por Fernando González Ollé (2014), que afirma que Salazar se oponía a los criterios estilísticos de la Academia. Según González Ollé (2014: cap. VIII), Salazar rechazaba el arcaísmo, el neologismo superfluo y el latinismo, y ponderaba la claridad y la concisión y la adecuación de la prosa al género literario del texto. Los dos principios de su ideario idiomático eran la defensa y la modernización de la lengua. Fundado en estos presupuestos, Salazar criticó duramente la Historia de la Iglesia y del Mundo, publicada por el académico Gabriel Álvarez de Toledo en 1713. La censura, titulada Carta del maestro de niños a don Gabriel Álvarez de Toledo, contenía algunas alusiones a la Academia, que se sintió ofendida y alentó las réplicas ${ }^{10}$. Según Fernández Ollé (cap. II), en la época fundacional, la Academia mantenía un sentimiento de comunión con el Barroco, adhesión que no era solo ideológica, sino que también se manifestaba en el estilo de ciertos académicos, lo que provocó el rechazo de algunos literatos de la época.

Es preciso señalar que Mayans, como después Vicente de los Ríos (Rey y Muñoz 2006: 69), consideraban al Quijote como el mayor monumento y homenaje que se había hecho a la lengua española ${ }^{11}$. El lenguaje de la obra adquiere así una dimensión de modelo estilístico y acaso normativo. Y las cuestiones estilísticas se hallan también en el fondo de la polémica que enfrentó a Montiano y Nasarre con Mayans a propósito de la comparación entre el Quijote de Cervantes y el de Avellaneda. Como es sabido, Mayans defendía la superioridad de la obra cervantina y censuraba el afrancesamiento de la corte, una de cuyas manifestaciones, además de la lengua y las costumbres, había sido la publicación del Quijote de Avellaneda a instancias de Nasarre y Montiano.

9. Lucía Megías (2016: 89) también sitúa la búsqueda de la "patria cervantina" en el contexto de las polémicas literarias y políticas de la época.

10. La Carta de Salazar tuvo su réplica en 1714: Palacio de momo [...], obra de Vicente Bacallar y Sanna, marqués de San Felipe, publicada bajo el seudónimo de Encio Anastasio y editada a instancias de «un amigo de Don Gabriel», según se dice en la portada. Según Ticknor (1856: t. IV, 26), Vicente Bacallar se consideraba seguidor de Gracián en poesía. Las censuras favorables de la Historia de Álvarez de Toledo eran obra de Juan de Ferreras y Juan Interián de Ayala, ambos académicos fundadores de la Real Academia.

11. Podría decirse que a partir de la edición académica del Quijote en 1780, que lleva al frente la Vida de Cervantes y el Análisis de la obra compuestos por Vicente de los Ríos, la obra cervantina se convertiría en el mayor exponente de las letras españolas. 
En efecto, animado por el juicio de Lesage ${ }^{12}$ sobre la superioridad de Avellaneda, Nasarre, bajo el seudónimo de Isidro Perales y Torres, reeditó el apócrifo en 1732. La aprobación de la obra era de Agustín Montiano.

Las opiniones de Mayans en la Vida de Cervantes no gustaron a Montiano y Nasarre, que se desquitaron en la crítica de Los origenes de la lengua española publicados por el valenciano en 1737, incluida en el segundo tomo (art. II) del Diario de los literatos de España ${ }^{13}$. La crítica era obra de Martínez Salafranca, aunque Mayans también veía la mano de Nasarre, Iriarte y Sarmiento en el artículo.

Bajo el pseudónimo de Plácido Veranio, don Gregorio replicó en Conversaciones sobre el Diario de los Literatos de España (1737), y los diaristas respondieron en el tomo III. En su respuesta, acusaban a Mayans de antiespañolismo aduciendo unos comentarios vertidos por el valenciano en el Acta eruditorum de Leipzig («Nova literaria ex Hispania», 1731), en los que censuraba también el Diccionario de autoridades. La disputa se prolongó hasta 1738, cuando se le encomendó a Mayans la censura de la España primitiva de Huerta y Vega, que había participado en la crítica a los Orígenes. Don Gregorio intentó evitar la publicación, que, no sin razón, le parecía una falsificación histórica, y se enfrentó a las dos Academias, pero, finalmente, prevaleció el criterio de la Academia de la Historia, cuyo director entonces era Montiano. La crítica de los diaristas a la obra de Huerta y Vega había sido favorable.

La polémica sobre el valor del Quijote de Cervantes y el de Avellaneda tiene, además, otra derivación. En efecto, en 1749, Nasarre incluyó una «Disertación o prólogo sobre las comedias de España» en su edición de Comedias $y$ entremeses de Miguel de Cervantes. Nasarre refutaba lo expuesto por Mayans en su Vida de Cervantes, y afirmaba que el teatro cervantino habría sido una parodia del Arte nuevo de hacer comedias como el Quijote lo sería de la novela de caballerías. La furibunda respuesta a las tesis de Nasarre no procedió entonces de Mayans, sino del sector tradicionalista o barroquista: Tomás de Erauso y Zabaleta (Ignacio de Loyola y Oyanguren), Francisco Nieto de Molina, José Carrillo ${ }^{14}$. Como se advertirá, en este punto, el cervantismo entronca con una de las cuestiones capitales de la literatura española del siglo XVIII: la reforma del teatro. En aquel momento, la discusión sobre la patria de Cervantes y otras polémicas tienen como contexto el deseo de modificar el modelo dramático español, y no debe soslayarse este hecho para entender que el ambiente cultural ya era polémico en sí. Se enfrentaban la tendencia

12. Lesage había publicado una traducción del Quijote de Avellaneda en 1704 (Nouvelles Aventures de l'Admirable Don Quichotte de la Manche, composées par le licencié Alonso Fernández de Avellaneda. París: viuda de Claude Barbín, 2 t.).

13. De esta y otras polémicas de la época nos hemos ocupado en Perdomo-Batista (2011).

14. En esta cuestión seguimos a Berbel Rodríguez (2003: 77-78). A Nasarre replicó también Pedro Estala (1794) por las críticas a Lope y Calderón. Acaso esta nueva discusión es continuación de los comentarios a La Poética de Luzán vertidos por Juan de Iriarte y Martínez Salafranca en el Diario de los literatos de España (t. IV). 
neoclásica y la tradición barroca. A estas disputas podría añadirse la suscitada mucho después con la publicación del Theatro Hespañol de Vicente García de la Huerta a partir de 1785, y en la que terciaron Samaniego y Forner.

Berbel Rodríguez (2003: 77, n. 96) ha señalado que a partir de las polémicas entre Nasarre, Montiano y Mayans, se inició una «carrera de obstáculos, a menudo convertidos en pequeñas trampas, para la captura de los datos que se le «escaparon» a Mayans: el certificado de la muerte de Cervantes (incluido por Nasarre en la última página de su Disertación) ${ }^{15}$, el lugar y la fecha del nacimiento de Cervantes (Montiano, II Discurso sobre las tragedias españolas, 1753 , en nota a pie de página) ${ }^{16}$.

A esta polémica habría que añadir, y no es asunto menor, y menos aún en relación con lo que nos ocupa, la discusión sobre el valor y la oportunidad de conocer e incluir los datos biográficos de los autores. Pues lo que se está cuestionando es la idea misma de historia literaria, que, a partir de la poliantea o la historia erudita y la apología barroca se va deslindando paulatinamente, a lo largo de la centuria, hacia la historia literaria propiamente dicha. Por eso, creo que el interés por la biografía de Cervantes también habría que interpretarla en el siglo XVIII en el contexto de las apologías de lo español.

En relación con la polémica sobre el valor e interés de los datos biográficos de los autores, Martín Sarmiento, en sus Reflexiones literarias para una biblioteca real (redactada hacia 1743 y publicada por Valladares de Sotomayor en 1789), afirmaba que, para evitar inútiles discusiones y pérdidas de tiempo sobre el lugar de nacimiento de un autor, era necesario dictar alguna ley «obligando a cualquier autor que haya de dar a luz e imprimir un libro, para que [...] noticie al público quién es, de dónde, qué estado y profesión tiene, qué empleos posee, qué edad tiene, cuándo nació y en qué parroquia está bautizado, qué padres tiene o ha tenido» ${ }^{17}$. Como señalan Santos Puerto y Santos Vega (2011: 33-34), lo más curioso es que el propio Sarmiento no cumplió lo que reclamaba, de modo que todavía no está del todo claro su lugar de nacimiento. Empero, fue él uno de los descubridores de la "patria" de Cervantes.

Por su parte, y mucho después que Sarmiento, Juan Sempere y Guarinos, en el Prólogo del segundo tomo de su Ensayo de una biblioteca española (1785-1789: II, VIII-IX) negaba el interés de las noticias biográficas de los autores en beneficio del contenido de las obras, «que es, dice, el que más debiera interesarnos». Y a continuación afirmaba lo siguiente:

Un sabio de nuestra nación se quejaba ya de semejante preocupación [prejuicio] a mitad del siglo XVI, atribuyéndolo a la decadencia de la famosa universidad de Alcalá. Desde entonces no ha disminuido; y mientras una nación no llegue a consolidar en su seno el espíritu de unidad y de patrio-

15. Blas Nasarre (1749: I, Disertación).

16. 1753, tomo II, p. 10, n. 7. Es certificación de la partida contenida en unos de los libros de bautismo de Santa María la Mayor, en Alcalá de Henares.

17. Cito por la edición de Santos Puerto (2002: 174-175). 
tismo, le faltan todavía muchos pasos que dar en la civilización. No es el mejor medio para extinguir la rivalidad entre las provincias el referir por menor las patrias de sus escritores. Antes, acaso, convendría sepultarlas en el olvido; a lo menos por cierto tiempo, y que de ningún hombre de mérito de nuestra nación se pudiera decir más que es español (Juan Sempere y Guarinos (1785-1789), t. II, pp. VIII-IX).

En la cita se advierte muy bien esa tensión entre lo local y lo general que a menudo hallamos en el pensamiento ilustrado y que a veces se ha interpretado como la prueba de la existencia de una, en mi opinión dudosa, Ilustración "local" (Perdomo-Batista 2012). El cervantismo es, por el contrario, un hecho global, tal y como lo formulara Bowle: «Cervantes ... honor y gloria no solo de su patria, de todo el género humano» (Rey y Muñoz 2006: 54). Y me parece que la propia tendencia dieciochesca hacia la formación de un canon literario es contraria al sentimiento local, que se halla más próximo a la mentalidad señorial.

Para terminar el apartado, solo nos resta añadir que todas estas polémicas tenían como fondo, además, las discusiones suscitadas por las cuestiones y las ambiciones estrictamente personales. Las más conocidas quizá sean las disputas de Mayans con Feijoo, y con los empleados de la Real Biblioteca y las dos Academias (Perdomo-Batista 2011 y 2017). De modo que el ambiente cultural e intelectual de la época debía ser poco menos que explosivo.

\section{SOBRE LA «PATRIA» DE CERVANTES}

Aunque, como hemos señalado, la «competición ${ }^{18} 》$ por descubrir documentos relacionados con la vida de Cervantes probablemente parte de los enfrentamientos de Mayans, Montiano y Nasarre ${ }^{19}$, las disensiones eran anteriores. En efecto, Tomás Tamayo de Vargas lo hacía oriundo de Esquivias (Ríos 1780: I, CLVX), Nicolás Antonio, en su Bibliotheca nova (1788: II, 133) había afirmado: «Michael de Cervantes Saavedra, hispalensis natu aut origine». A Antonio lo siguió Ortiz de Zúñiga en sus Anales (1677: 590). Y, según Aguilar Piñal (1983: 155), Lope, en el Laurel de Apolo, había sugerido que Cervantes era de Madrid. Así es que la cosa distaba de estar clara cuando Mayans expuso en su Vida que Cervantes era de Madrid. Y, aunque era libro raro, la referencia a Alcalá contenida en la Topografía de Haedo no era del todo desconocida, porque la había expuesto claramente Méndez de Silva (1648: 60), como señala Pellicer (1788: 162).

18. "La carrera hacia Alcalá", llama José César Álvarez (2005) a los empeños por descubrir el lugar de nacimiento de Cervantes. Según Fernández Navarrete, se involucraron Mayans, Sarmiento, Iriarte, Montiano, Pingarrón, Nasarre, Cano, Ríos y Pellicer. Y señala que la búsqueda trascendió las fronteras: Floriau y Dubournial en Francia, Jarvis y Bowle en Inglaterra, Weyermen en Holanda.

19. Al respecto, nótese que Montiano incluyó la copia de la partida de bautismo de Cervantes al final del II Discurso sobre la Tragedia española sin venir a cuento. 
Así estaban las cosas cuando en 1743 Sarmiento confesaba a Juan de Iriarte (Santos Puerto 2002: 263) 20: «iQué cosa más lastimosa que no saber al presente la patria de Cervantes, habiéndose hecho tan famoso por su Historia de Don Quijote?». Para entonces, Sarmiento ya estaba tras la pista de Alcalá, porque, como él mismo revela en 1752 en su Disertación sobre el animal Zebra (Santos Puerto y Santos Vega 2013: § 51//17//): «... y advierto, de paso, que en llamar Cervantes a la capital, la Gran Compluto, miraría acaso a señalar su patria con aquel elogio de grande; siendo cierto que, según la Historia de Argel del P. Haedo, era Miguel Cervantes un hidalgo principal de Alcalá de Henares».

Así pues, Sarmiento confirmó sus sospechas en la Topografía e historia de Argel de Fr. Diego de Haedo, y a partir de ahí el camino hasta Alcalá parece expedito. El benedictino había reparado en la obra de Haedo porque en 1752, al parecer a instancias del conde de Maceda, se había interesado por la antigua existencia de cebras en la Península. Sarmiento comentó la noticia de su hallazgo al librero Manuel de Mena para que la difundiera y alguno se empleara en localizar en Alcalá la partida de bautismo de Cervantes, y así lo hizo Mena. La noticia llegó a Mayans a través de su confidente Manuel Martínez Pingarrón, que le comunicaba (carta del 09-06-1752, disponible en Mayans Digital) su intención de pedir la partida de bautismo en Alcalá.

No obstante, y según el testimonio de Bernardo de Iriarte, al que nos referiremos después, hacia 1748, su tío, el bibliotecario real Juan de Iriarte, había localizado en la Real Biblioteca una relación de cautivos publicada en Granada en la que se expresaba que Miguel de Cervantes era natural de Alcalá. El testimonio de Bernardo fue publicado por Pellicer en 1778, y dio origen a la discusión sobre el verdadero descubridor de la «patria» de Cervantes, pues, a partir del relato del sobrino de Iriarte se deduce que lo que habría puesto a Sarmiento en la pista de Haedo es la relación de cautivos hallada por su tío. Sea como fuere, estos avances condujeron al hallazgo de la partida de nacimiento de Cervantes en la iglesia de Santa María la Mayor de Alcalá. La partida fue publicada primero por Montiano en su II Discurso sobre las tragedias españolas, y después por el bibliotecario real y confidente de Mayans, Manuel Martínez Pingarrón, que la editó en el Ensayo de Pellicer (1778). La publicación de la partida de bautismo daría lugar a una nueva discusión sobre quién la había obtenido primero, porque Martínez Pingarrón y su círculo consideraban que había sido él, y que la fecha de obtención de la partida de Montiano se había amañado para que pareciera que este la había obtenido primero. Santos Puerto y Santos Vega (2011: 38-41) sostienen que Montiano obtuvo la partida primero y que las sospechas de

20. Así consta en Reflexiones literarias para una biblioteca real y para otras bibliotecas. Fueron editadas en 1789 por Antonio Valladares en el Semanario Erudito (X-XI: 99-273). La obra consta de dos partes escritas a modo de cartas dirigidas a Juan de Iriarte, aunque al parecer solo la primera fue redactada a instancias del bibliotecario (Santos Puerto 2002: 21-23, 38). 
Pingarrón, aunque comprensibles, pueden disiparse examinando detenidamente los hechos.

La polémica sobre la cuna de Cervantes arreció cuando en 1758 (Pellicer 1778: 191) se dio a conocer una partida de nacimiento de Cervantes de Alcázar de San Juan. Para impugnar la nueva hipótesis, Sarmiento (1761) redactó Noticia sobre la verdadera patria (Alcalá) de Él [sic] Miguel de Cervantes. Repárese en la mayúscula del artículo, que refuerza su valor deíctico.

Desde la publicación de Pellicer y hasta fecha más o menos reciente, generalmente se aceptaba que a ambos, Sarmiento e Iriarte, correspondía el descubrimiento, y buena parte de los cervantistas atribuyen a este último el hallazgo. Sin embargo, en el II Discurso sobre las tragedias españolas (1753, t. II, 9) Montiano atribuyó el descubrimiento a Sarmiento y no mencionó a Iriarte, lo que tampoco resulta tan extraño dados la proximidad entre ambos y los enfrentamientos con Mayans. En carta del 12-08-1752 (Mayans Digital), Martínez Pingarrón comunicó a Mayans que se había hallado la partida siguiendo las indicaciones de Sarmiento. En la edición académica del Quijote, Vicente de los Ríos (1780: clxvi) señala los hallazgos de Sarmiento, pero no menciona a Iriarte. No debe extrañarnos, porque en el prólogo de la Academia (1780: I, XIV) se nos aclara que Vicente de los Ríos había escrito su Vida de Cervantes y la había leído antes de que Pellicer publicara su Ensayo. De ser así, me parece muy extraño que Ríos no corrigiera su texto final para incluir las noticias de Pellicer. El comentario de la Academia establece que tanto Ríos como Pellicer habían trabajado de forma independiente, y que se debía reconocer a cada uno su mérito. Creo que, de esta forma, la Academia pretendía avalorar el trabajo de Ríos y, de paso, salvaguardar su propia edición del Quijote. Empero, Fernández de Navarrete (1819: 207) sí reconoce la aportación de Iriarte y recoge el relato de su sobrino.

No debemos olvidar que en 1764, José Miguel de Flores y la Barrera había publicado en el número XXVI de Aduana crítica una «Carta sobre la patria de Miguel de Cervantes». La carta es un buen relato de la polémica y de sus pormenores. Flores refiere los avances de Sarmiento, pero no menciona a Iriarte, porque, en la fecha en que publica su Carta, Pellicer aún no había publicado el testimonio de Bernardo de Iriarte.

En todo caso, el dato del lugar de nacimiento de Cervantes era tan importante como para modificar la Vida de Mayans en las ediciones del Quijote de Manuel Martín: «Sin embargo de que en esta Vida se sienta que CERVANTES es natural de Madrid; posteriormente se ha averiguado con certeza ser natural de la Ciudad de Alcalá de Henares. FIN DE LA VIDA DE CERVANTES» (Rodríguez Cepeda 1988: 12). En un artículo reciente, Santos Puerto y Santos Vega (2011) atribuyen el descubrimiento del lugar de nacimiento de Cervantes a Sarmiento y ponen en duda la participación de Iriarte. Los argumentos que exponen son muy similares a los de Rey y Muñoz (2006) y a los expuestos en su día por Pensado, y pueden resumirse del siguiente modo: 1) la fecha en que Bernardo sitúa el descubrimiento de su tío (1748) no coincide con la fecha en la que Sarmiento empezó sus indagaciones (tres años después); 2) 
¿por qué Iriarte acudió a Sarmiento y no exploró él mismo las posibilidades de su descubrimiento?; 3) ¿por qué Sarmiento no dio noticia del descubrimiento de Iriarte?; 4) ¿por qué no contamos con otros testimonios que avalen el relato de Bernardo de Iriarte y por qué este esperó tanto para hacer valer los méritos de su tío? y, 5) ¿Juan de Iriarte llegó a conocer la Relación de cautivos impresa por Rabut (Santos Puerto y Santos Vega 2011: 47)? Para dar respuesta a estos interrogantes, o al menos para situarlos en la perspectiva adecuada, debemos examinar los testimonios de las partes interesadas y algún otro que aún no ha sido tenido en cuenta. A ello dedicaremos los siguientes apartados.

\section{El testimonio de SARMiEnto}

El P. Sarmiento nos dejó tres testimonios de su descubrimiento de la patria de Cervantes que mencionamos a continuación ordenados cronológicamente (no se incluye el texto de las Reflexiones literarias para una Biblioteca Real, donde plantea la necesidad de averiguar el lugar):

1) Disertación sobre el animal Zebra, redactada en 1752.

2) Noticia de la verdadera patria (Alcalá) de Él Miguel De Cervantes, redactada en 1761 .

3) Índice individual de los 6500 volúmenes de libros, y algunos más, que este año de 767 poseo 'ad usum', redactado, como se indica en el título, en 1767. Así lo citan Santos Puerto y Santos Vega (2011: 37, n. 15), pero en el catálogo de manuscritos de la Real Academia de la Historia figura de esta forma: Catálogo de los Autores de quienes yo Fr. Martín Sarmiento tengo obras. Real Academia de La Historia, un volumen en 4. ${ }^{\circ}$ Encuadernado en pergamino. Ms. 9-1829. Sarmiento se refiere a su descubrimiento dos veces, en la entrada correspondiente a Cervantes y en la de Haedo.

A tenor de lo anterior, creo que no se puede afirmar, como hacen Santos Puerto y Santos Vega (2011: 45), que Sarmiento «no pretendía la fama relacionada con el nacimiento de Cervantes». Al contrario, se ocupó de dejar constancia de su hallazgo y documentarlo muy bien (cita el descubrimiento en tres textos, en uno de ellos, el Índice o catálogo de sus libros, lo hace dos veces e incluso indica el mes en que ocurrió). Me parece evidente que es demasiada insistencia para alguien enteramente despreocupado de la fama.

Según el testimonio de Sarmiento en la Disertación sobre la zebra (Santos Puerto y Santos Vega 2013: II-III), en 1752 se hallaba ocupado, por encargo del Conde de Maceda, en averiguar la historia de la cebra en España, pues consideraba que estos animales habían habitado en la Península, y que debían ser restituidos a España. Indagando sobre la cebra tropezó con la Topografía e historia general de Argel de Diego de Haedo, y en el «Diálogo de los mártires» (p. 185) halló la referencia al autor del Quijote: Miguel de Cervantes un hidalgo principal de Alcalá de Henares. 
Para Santos Puerto y Santos Vega (2011: 43), la consulta del libro de Haedo había coincidido con otro hecho. En efecto, en sus pesquisas sobre la cebra, Sarmiento había consultado el tomo VI del Diccionario de Autoridades (1739), que incluía, bajo la voz «zebra», un pasaje del Quijote: «Haré quenta que voy caballero sobre el caballo Pegaso, sobre la cebra, o alfana, en que cabalgaba aquel famoso moro Muzaraque, que aun hasta ahora yace encantado en la gran cuesta Zulema, que dista poco de la gran Compluto» (t. I, cap. 29). Y por cierto que la definición y el ejemplo, no vienen bajo la voz «zebra», sino en la entrada «cebra», contenida en el tomo II (1729: 250-251) ${ }^{21}$. La tercera línea de la cita no viene en el Diccionario, por lo que Sarmiento debió acudir al Quijote, en el que encontraría la referencia a Alcalá. Y por eso afirma: «... advierto de paso que en llamar Cervantes a la capital la gran Compluto, miraría acaso a señalar su patria con aquel elogio de grande, siendo cierto que según el padre Haedo era Miguel de Cervantes un hidalgo principal de Alcalá» (Santos Puerto y Santos Vega 2013: 12).

Debe notarse que en las palabras de Sarmiento se advierte cierta duda, como ya señaló Fernández de Navarrete (1819: 208). La duda de Sarmiento es comprensible si tenemos en cuenta que Haedo solo dice que Cervantes era «un hidalgo principal de Alcalá», no que hubiera nacido allí. Sabemos que los hidalgos tenían casa solariega en su municipio, pero a veces se avecindaban en otras localidades. El concepto de hidalguía, además, es muy complejo y no permaneció inmutable ${ }^{22}$. Así que la cuestión era dudosa ${ }^{23}$. Por el contrario, en la Relación de cautivos hallada por Juan de Iriarte sí se citaba a un Miguel de Cervantes «natural» de Alcalá y cautivo en Argel. De modo que podemos concluir que, aunque Sarmiento descubriera la patria de Cervantes, carecía de la prueba documental. Tal prueba pudo ser, primero, la Relación de cautivos, y posteriormente sería la partida de bautismo hallada en Alcalá. Ahora bien, el Miguel de Cervantes bautizado en Santa María la Mayor no necesariamente tenía que ser el autor del Quijote, podía ser cualquier "Miguel de Cervantes", como, por ejemplo, el bautizado en Alcázar de San Juan, cuya partida se descubrió en 1758. Era necesario un documento que vinculara al «Cervantes autor del Quijote» con Alcalá. Era necesario, digámoslo así, «triangular» el dato de Alcalá, y eso es, precisamente, lo que ofrecía la Relación de Iriarte. Creo que todo ello explica las dudas de Sarmiento pese a su aguda y certera intuición inicial. Estas dudas se advierten claramente en la Noticia (p. 1) redactada en 1761, en la que se sirve de los datos disponibles y de la cronología para impugnar la partida de bautismo de Alcázar de San Juan. El texto se titula «NOTICIA de la Verdadera PATRIA (ALCALÁ) de ÉL [sic]

21. Accesible en: <http://www.rae.es/recursos/diccionarios $>$.

22. Pueden verse, por ejemplo, Ladrón de Guevara (2011) y Pérez León (2010).

23. Y tampoco está exento de problemas el concepto de «patria», pues aunque el Diccionario de Autoridades es claro («El Lugar, Ciudad o País en que se ha nacido», tomo V, 1737), «la corte es patria común, y cualquiera la puede llamar con este nombre», como se señala en Aduana Crítica (1764, t. III, p. 261). Sobre la idea de patria en el siglo XVIII puede verse Perdomo-Batista (2012). 


\section{MIGUEL DE CERVANTES estropeado en Lepanto, cautivo en Argel y autor de la historia de Don QUIXOTE»; y comienza así:}

En las dos letras ÉL, que, con cuidado, puse en el título, consiste el que ninguno se deba ya preocupar con otras noticias de la patria del famoso Cervantes. No se inquiere aquí la patria de un quidam Miguel. No la de un tal Miguel de Cervantes; ni la de un tal cual Miguel de Cervantes Saavedra. El nombre Miguel es muy trivial. El apellido Cervantes es comunísimo, y aún es más común el apellido Saavedra. Y la unión de los dos CervantesSaavedra nada tiene de singular. Lo que aquí se piensa averiguar es la patria de Aquel o de ÉL Miguel de Cervantes Saavedra, cuyo nombre es tan celebrado y aplaudido en toda España, y aún más en las naciones extranjeras por su ingeniosa novela de el maniático fingido Don Quijote de la Mancha. Esto servirá después, no para darla por falsa, sino para convencerla de insuficiente cierta certificación de una fe de bautismo que en lo adelante se citará contra lo que yo asentiré.

Queda claro que para Sarmiento era necesario desambiguar las partidas de nacimiento, porque no bastaba que fueran de Miguel de Cervantes, sino que debían ser del Cervantes autor del Quijote. De ahí que, por su valor deíctico, en el título escribiera el artículo como pronombre (con tilde) y lo subrayara.

Además, el libro de Haedo ${ }^{24}$ era obra literaria y no gozaba precisamente de buen crédito, pues como señala Martínez Pingarrón a Mayans en carta del 24 de junio 1752: «Aunque D. Nicolás Antonio no le elogie, en lo que yo he visto de él no me ha parecido mal». Pingarrón no envió directamente el libro a Mayans, sino que esperaba la confirmación del interés de este. Las dudas sobre la obra de Haedo nos las expone el propio Sarmiento en su Noticia (1761: 11):

En el año de 1717, estando en este mi monasterio de San Martín de Madrid, bajaba con frecuencia a la Librería, que contiene 9000 tomos. No tanto bajaba a leer, cuanto a enredar y revolver libros. Sucedió que entre ellos tropecé con uno en folio cuyo título era: Topografia e historia general de Argel. Su autor el M. ${ }^{\text {ro }}$ P. ${ }^{\mathrm{e}}$ Fr. Diego de Haedo, benedictino ${ }^{25}$. Leí un poco de la Topografía y me pareció muy bien. Pero preocupado de que un monje benito no podría notar con exactitud y acierto las cosas de Argel, desamparé aquel libro y eché mano de otro para divertirme. Después no volví a ver ese P. ${ }^{\mathrm{e}}$ Haedo hasta el año de 1752.

24. La autoría ha sido discutida. Eisenberg (2003) la atribuye al propio Cervantes; Emilio Sola y José M. ${ }^{a}$ Parreños (Sosa 1990) al doctor Antonio de Sosa. Sobre esta última hipótesis, puede verse también Aurelio Vargas (2018).

25. En el Catálogo de la Biblioteca de San Martín, redactado en 1730, según figura al principio, consta que por entonces existía un ejemplar de la Topografía de Haedo (es la primera entrada de la letra $H$., p. 99), lo cual resulta bastante lógico, pues su autor era también benedictino. Puede consultarse en la Biblioteca Digital Hispánica: Índice de los libros que contiene la Biblioteca de este Real Monasterio de San Martín de Madrid. 
Y no debemos olvidar que por entonces Mayans (1737) había publicado en su Vida que Cervantes era de Madrid, y que ya había tenido enfrentamientos con Montiano y con otros literatos de la corte próximos a Iriarte y Sarmiento.

Así que los recelos del benedictino no carecerían de fundamento. Quizá fue la Relación de Iriarte lo que dio firmeza a sus conjeturas y le dio seguridad para hacerlas públicas y para alentar la búsqueda en Alcalá. Y adviértase, además, que estamos hablando de dos cosas diferentes: el descubrimiento de la patria de Cervantes y su confirmación documental. Lo primero correspondería a Sarmiento; lo segundo, a Iriarte o a quienes hallaron la partida de bautismo en Alcalá (aunque las partidas en sí mismas, como hemos visto, no bastaban). Por lo demás, creo que una vez hallada la partida de bautismo en Alcalá y las partidas de rescate conservadas en el Convento de la Trinidad en Madrid (publicadas por Pellicer 1778: 195-197), la Relación de cautivos perdería su valor documental, lo cual explicaría entre otras razones, el silencio de Iriarte y también de Montiano y Sarmiento, que eran colaboradores y ya tenían su lugar asegurado en la historia del descubrimiento. No tiene nada de extraño que Sarmiento se considerara el autor del hallazgo: de él había partido el interés y la iniciativa inicial, según expone en las Reflexiones literarias $^{26}$, fue él quien motivó a Juan de Iriarte; fue el primero en intuir que Cervantes era de Alcalá y el primero en divulgarlo para que se localizara su partida de bautismo, de modo que marcó el camino que siguieron tanto Iriarte como quienes hallaron la partida en Alcalá. Y lo mismo debía pensar Iriarte.

Por otra parte, y para finalizar, no se explica muy bien cómo llegó Sarmiento del texto quijotesco sobre la cebra a la cita exacta de Haedo contenida en el «Diálogo segundo de los mártires». Sarmiento habla de su hallazgo como algo casual, lo cual desde luego no invalida su testimonio, pero ciertamente le resta fuerza: «Leyendo yo por abril de 752 la Historia de Argel de Fr. Diego de Haedo, tropecé con una columna de la página 185, que toda habla de este Miguel de Cervantes, cautivo en Argel» (Santos Puerto y Santos Vega 2013: X, n. 6). La referencia al mes es una prueba del interés del benedictino por dejar constancia de su contribución al descubrimiento, y, aunque sabemos de la meticulosidad de Sarmiento, parece excesiva. Por su parte, la explicación que dan Santos Puerto y Santos Vega (2011: 43) me parece algo forzada, y, además, tampoco deja de ser casual: Sarmiento habría acudido al índice de la obra de Haedo, no encontraría nada relacionado con la cebra, ni en la $\mathrm{C}$ ni en la $\mathrm{Z}$, pero acaso pudo fijarse en esta noticia que aparecía en la tabla final, letra $\mathrm{C}$ : «Vn Cautivo Christiano es muerto a puñaladas en Biserta y por qué. 185.2»; abrió el libro por esa página y justo allí, en la columna primera, halló la noticia sobre Cervantes.

26. La obra está escrita como una carta dirigida a Juan de Iriarte, pero se trata de un recurso literario. Como señala el propio Sarmiento a Rávago: «... el dicho Yriarte ni siquiera una letra vio de los 19 pliegos» (Varela-Orol 2016: 695). 


\section{Los testimonios de Pellicer y Bernardo de Iriarte}

En 1778, Juan Antonio Pellicer y Saforcada publicó su Ensayo de una bibliotheca de traductores españoles. En la obra, Pellicer incluyó unas «Noticias literarias para la vida de Miguel de Cervantes», y añadía una serie de documentos: carta de Bernardo de Iriarte, a la que enseguida nos referiremos; la partida de bautismo de Cervantes localizada en Santa María la Mayor de Alcalá, obtenida por Martínez Pingarrón, acompañada de una carta de Santiago Gómez Falcón, abad de San Justo en Alcalá; otra carta de este último a Martínez Pingarrón ${ }^{27}$; copia de la partida de bautismo de Alcázar de San Juan; una carta de Antonio Ramírez, beneficiado de Esquivias, y una esquela del párroco de esta localidad sobre la fe de estado civil de Cervantes, remitidas ambas a Martínez Pingarrón; copias de las partidas de rescate de Cervantes conservadas en el convento de la Santísima Trinidad de Madrid, acompañadas de un certificado de Fr. Alonso Cano, obispo de Segorve, redentor general y ministro provincial de Castilla; copia de la partida de defunción de Cervantes de la parroquia de San Sebastián de Madrid. La abundancia de documentos y la preocupación por el rigor y la fidelidad históricos dan idea de la complejidad de la cuestión que nos ocupa y de lo polémica y delicada que llegó a ser.

En su «Noticia», y en nota a pie de página (p. 143, n. 2), Pellicer relata:

Recorriendo algunos libros de la Real Biblioteca, encontré casualmente una
Relación impresa en Granada el año de 1581 por René Rabut de 185 cau-
tivos rescatados en Argel el año antecedente por los PP. Fr. Juan Gil y Fr.
Antonio de la Bella, del Orden de la Santísima Trinidad, Redentores por
las provincias de Castilla y Andalucía; y entre las primeras partidas leí esta:
Miguel de Cervantes, de edad de 30 años, natural de Alcalá de Henares.
Tratando después de este hallazgo con Don Bernardo de Iriarte, Oficial
Mayor de la Primera Secretaría de Estado, Académico de la Real Academia
de la Lengua Española, sujeto de no vulgar literatura, me dijo que su tío
don Juan de Iriarte, bien conocido en la república Literaria por su erudición
grecolatina había descubierto muchos años antes por igual casualidad esta
misma Relación en la referida Real Biblioteca; y que comunicando la es-
pecie de Cervantes con el erudito P. Maestro Sarmiento, acudió este a la
Historia y Topografía de Argel de Fr. Diego de Haedo publicada en 1612.

Pellicer continúa relatando cómo Pingarrón había sacado la partida de nacimiento de Cervantes en Alcalá, y al final viene a sugerir que Montiano se había adelantado a Pingarrón con malas mañas, pues habría pedido que se modificara la fecha de expedición de su copia de la partida. No advierto en Pellicer parcialidad favorable a Bernardo de Iriarte, pues, si bien incluye el relato de este, también recoge la partida de Pingarrón y las cartas relacionadas,

27. Las cartas de Gómez Falcón y la partida de Pingarrón son el núcleo de la polémica sobre si fue este o Montiano el primero en obtener el documento, cuestión a la que ya nos hemos referido. 
además de la partida de Alcázar (el que queda fuera es Montiano). Tampoco hallo razón para dudar de su testimonio (¿por qué mentir y añadir, además, el testimonio falso de Bernardo?).

En su «Carta» (Pellicer y Saforcada 1778: 186-188), Bernardo de Iriarte contaba lo siguiente (se disculpará la extensión de la cita en atención a su interés y oportunidad):

Por los años de 1748 llegué yo a Madrid de Canarias; y desde luego oí hablar a mi tío don Juan de Yriarte con varios literatos amigos suyos, y señaladamente con el P. M. Fr. Martín Sarmiento, de las diligencias que hasta entonces se habían practicado inútilmente para averiguar la patria de Cervantes. Poco tiempo después, entrando mi tío en su casa de vuelta de la Bibliotheca Real [...] me dijo estas o parecidas palabras: Al fin he descubierto la patria de Miguel de Cervantes Saavedra, autor de la historia de Don Quixote. Leyendo hoy mismo en la Real Librería una relación antigua de varios cautivos rescatados por aquellos tiempos en Argel, he visto citado entre ellos, con expresión de la edad que por entonces tenía, a Miguel de Cervantes Saavedra, natural de Alcalá de Henares. Quiero ir mañana mismo a decírselo al P. Sarmiento. En efecto al día inmediato dio en mi presencia la noticia a aquel curioso erudito [...], y al despedirnos, le dejamos ya proyectando hacer diligencias para la comprobación de la especie. $[\ldots]$

Publicó Don Agustín Montiano su Discurso segundo sobre las tragedias españolas, y sorprendido yo de que se atribuyese al P. Sarmiento el descubrimiento que había sido de Don Juan de Yriarte, lo advertí a este que con su natural moderación no hizo gran caudal del asunto, satisfecho de que se hubiese publicado la noticia. Pero igual suerte tuvo este literato con otro descubrimiento suyo, quiero decir con el del sistema de circulación de la sangre, que leyó en el libro de albeitería de Francisco de la Reyna, impreso en Burgos el año de 1564, mucho antes de que existiese el inglés Guillermo Harveo [William Harvey], a quien posteriormente se atribuyó. Tengo bien presente que a mí mismo me hizo copiar el capítulo en el que Francisco de la Reyna explicaba el mecanismo de la circulación de la sangre, y que entregó copia al P. Sarmiento para que la enviase al P. Feijoo (1781); mas aunque el célebre benedictino insertó en su carta XXIII del tomo III algunas palabras de aquel texto ponderando el hallazgo [...] calló al público quién era el sujeto a quien originariamente se debía [...] San Ildefonso a 20 de agosto de 1772.

Respecto de la carta de Bernardo de Iriarte, es preciso indicar algunas cuestiones.

Tengo por muy poco probable que Bernardo falseara su testimonio. Era hombre de carácter recio y, al decir de quienes lo conocieron, extremadamente orgulloso (Cotarelo y Mori: 2006). ¿Para qué iba a poner en juego la reputación de su tío y aun la suya? Hacia 1772, al año de la muerte de don Juan, los Iriarte se hallaban en la cumbre de su poder, y no me parece que necesitaran méritos espurios. 
En cuanto a la fecha (1748), una de las principales objeciones que se ponen a su testimonio, Bernardo no dice que el descubrimiento de su tío se produjera ese año, sino que por aquel entonces llegó a Madrid. Por otra parte, quizá confundió la fecha de su llegada, aunque quien tenga noticia de su carácter sabrá que era hombre de mente clara y firme. Tenía entonces Bernardo 13 años; sus hermanos Domingo y Tomás llegaron a Madrid con 15 y 14 años respectivamente, $\mathrm{y}$ en ese sentido la fecha parece coherente.

En cuanto al desinterés de don Juan por reclamar su participación en el descubrimiento, según cuenta su sobrino Bernardo, es preciso señalar algunas cuestiones. En efecto, era hombre de gran moderación y prudencia (Cotarelo y Mori 2006). Muy probablemente, y salvando las distancias, Iriarte era colaborador de Sarmiento como este lo era de Feijoo, a quien aportaba datos y noticias. Debe advertirse que en ese momento no se había consumado aún la sustitución de la fraternidad de los miembros de la República Literaria (caracterizada por la colaboración desinteresada) por la competitividad del escritor moderno independiente. Don Juan era, por el contrario, un humanista al viejo estilo. Y en este contexto, hubiera sido difícil que polemizara o discutiera con Sarmiento, por quien seguramente sentía gran consideración y respeto, y mucho menos considerando la similar colaboración de Sarmiento con Feijoo. Y a ello hay que añadir el clima polémico de la época, que seguramente desaconsejaría a don Juan cualquier polémica (recordemos que Mayans había publicado su Vida en 1737, y que ya había tenido diferencias con Feijoo y Montiano y con los círculos de la Real Biblioteca, las Reales Academias y el Diario de los Literatos de España). Debemos recordar, además, que en 1751 falleció Blas Nasarre, bibliotecario mayor, y entonces algunos empleados de la Real Biblioteca, entre ellos don Juan, pretendían la vacante. Iriarte no logró el puesto, pero, quizá como compensación, ese mismo año obtuvo del rey una pensión de 300 ducados anuales además del sueldo de bibliotecario (lo sabemos por carta de Pingarrón a Mayans del 10-07-1751). En tales circunstancias, ¿hubiera sido prudente y oportuno polemizar o aun arriesgar su prestigio públicamente?).

Y en cuanto al descubrimiento de la circulación de la sangre por el albéitar español Francisco de la Reyna ${ }^{28}$, es preciso señalar que en el tomo III de la edición de 1781 de las Cartas eruditas, el editor insertó una nota (pp. 403404) que precisa:

El docto bibliothecario de S. M. don Juan de Iriarte, íntimo amigo del P. Mro. Sarmiento, fue quien observó esta especie [descubrimiento de la circulación de la sangre por Francisco de la Reyna] y quien le comunicó copia íntegra del capítulo de Francisco de la Reyna. Ha parecido oportuno insertar aquí un tanto de él en toda su extensión, habiéndole trasladado del mismo exemplar donde le leyó, y de donde le hixo copiar Don Juan de Iriarte, que conservan con debida estimación los sobrinos de aquel célebre literato.

28. Sobre la obra de Francisco de la Reyna puede verse Mercedes Fernández (2000-2007). 
Pensado (1987) sugiere que el enfado por la omisión de la referencia a don Juan en el hallazgo del descubrimiento de Francisco de la Reyna, que parece dar por bueno, fue lo que motivó el testimonio de Bernardo. Ahora bien, no se advierte por qué razón uno de los testimonios de Bernardo (precisamente el que beneficia a Sarmiento y perjudica a Iriarte) tendría que ser falso y el otro verdadero, y por qué no podrían ser ambos falsos o, mejor aún, ambos verdaderos. Parece que nos hallamos ante un prejuicio, motivado seguramente por el enorme prestigio que el benedictino ha ido adquiriendo en las últimas décadas frente al relativo olvido de Iriarte. Es importante señalarlo porque el juicio de Pensado ha influido en los investigadores posteriores.

\section{El testimonio de García de Armesto}

José García de Armesto fue capellán del rey en la Real Capilla y Monasterio de la Encarnación de Madrid. Fue también un conocido bibliógrafo. En la Biblioteca del Palacio Real de Madrid (http://www.realbiblioteca.es) se conserva un documento de 4 páginas mecanografiadas dirigido al rey Alfonso XIII. Se trata de un memorando sin data en el que García de Armesto le comunica al monarca el hallazgo de una Relación de 185 cautivos que en el año 1580 rescataron en Argel los PP. Fr. Juan Gil y Fray Antonio de La Bella, impresa en Granada en 1581 por René Rabut, y entre cuyas partidas figura una correspondiente a «Miguel de Cervantes, de edad de 30 años, natural de Alcalá de Henares». El documento se halla en el facticio II/4059: Papeles varios mecanografiados del reinado de D. Alfonso XIII, años 1916-1923. La signatura topográfica es II/4059. No he visto citado este documento, por lo que creo que se ha pasado por alto.

La noticia del hallazgo de García de Armesto fue publicada en $A B C$ (30-

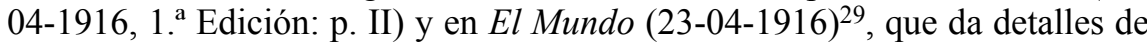
la edición de la Relación: «El documento que tan feliz comprobación ofrece es una relación de 185 cautivos, con licencia del señor comisario de la Santa Cruzada, en casa de René Rabut. La encuadernación, no cabe duda de que es del siglo XVI, así como la impresión. En la hoja segunda vuelta, de las nueve que contiene la relación, y en la correspondiente a los 105 hombres, dice textualmente: "Miguel de Cervantes, de edad de 30 años, natural de Alcalá de Henares"».

En su informe, García de Armesto expone:

Indudablemente es el mismo [que ha descubierto Iriarte en la Biblioteca Real]. Porque tiene los sellos de la Real Biblioteca y las varias signaturas con que figuró en los índices. Además porque en la página en donde se 
encuentra el nombre de Cervantes se hallan colocados en el margen de dicha página unos signos que no cabe duda son de la mano de Iriarte.

El personal y quienes se hallaban familiarizados con los volúmenes de la Real Biblioteca podían reconocer la letra de los bibliotecarios. No es extraño, por tanto, que García de Armesto - como probablemente le sucedería en su día a Pellicer, y por eso acudiría a Bernardo de Iriarte- reconociera la letra de don Juan.

García de Armesto señalaba en su informe que la Relación hallada por él era «ejemplar único». La Relación fue recogida por Bonifacio Porres Alonso (1997: 54) de la siguiente forma:

85. 1581 Memorial de una redempción de captivos que la provincia de Castilla y Andalucía de la orden de la Santísima Trinidad de la Redempción de captivos hicieron por mandado de su Magestad y de los Señores Presidente y Oydores de su Real y Supremo Consejo en la ciudad de Argel de berbería en el año 1580 [...] (Al fin: Granada, René Rabut, 1581). Contiene catálogo de 185 cautivos, y al final unas apreciables noticias sobre Juan Gil. Antonino de la Asunción lo reimprimió en «Revista Trinitaria» 2 (1896-1897: 111-115, 141-144), tomándolo del Ms. 3584. Madrid. Nacional, Ms. 3584, ff. 35-42. Copia de Juan Figueras Carpi, ca. 1650.

Y en efecto, el P. Antonino de la Asunción, trinitario descalzo, Ministro de la Orden, publicó el texto en la Revista Trinitaria. El pie de impresión, por cierto, coincide plenamente con el señalado por García de Armesto y con lo publicado por El Mundo en 1916: «Impreso con licencia del Señor Comissario de la santa Cruzada en Granada en casa de Reue Rabut año de $1581 »^{30}$. $\mathrm{Y}$, obviamente, en la página 113 figura «Miguel de Cervantes, de edad 30 años $^{31}$, natural de Alcalá de Henares». También cita el documento Pérez Pastor (1897-1902, II, doc. XXIV). El P. Domingo de la Asunción (1917: 132) señala que la Relación de Cautivos se imprimió también en Madrid y «se envió a todas las partes de España, para que llegase a conocimiento de las familias de los redimidos».

Y recoge dos impresiones de la redención de 1580:

Memorial de 185 cautivos rescatados en Argel el año pasado de 80. Granada, René Rabut, 1581.

Discours du rachat de cent quatre -vingt et six, tan chrétiens que chretiennes, tous captips d'entre les mains de Turcs et basrabres, evec leurs noms, surnomes et captivités. Le tout fait per les religieux Trinitaires Redemption

30. En la Real Biblioteca aún se conservan algunos libros impresos por René Rabut en Granada, como puede comprobarse a través de su catálogo en línea (http://www.realbiblioteca.es/).

31. Adviértase que la edad de Cervantes señalada por Pellicer y García de Armesto y el P. Asunción coinciden, aunque en las copias de las partidas de rescate publicadas por Pellicer (1788: 195-196) figura 33 y 31 años. La coincidencia de Pellicer y García de Armesto no debe ser pasada por alto, y me parece una prueba de la coherencia de sus testimonios. 
des Captifs; ensemble le rechat de quelques saintes reliques. A Paris, G. Chaudiere, 1582 , in $8 .^{\circ}$

El P. Asunción añade que el periódico La Patrie (París) mencionó el último impreso en un artículo cervantino publicado en el número del 29 de septiembre de 1863, según noticia de Leopoldo Augusto de Cueto.

Pérez Pastor (1897: I, 243) cita tres ediciones de la Relación de 185 cautivos:

- La de Madrid, que debió hacerse en 1581 a la llegada de los últimos cautivos.

- Relación de 185 captivos rescatados de Argel el año pasado de 80. Granada, René Rabut, 1581. Según Pérez-Pastor, fue la que vio Pellicer (y, consecuentemente, Iriarte).

- Rachat de 185 captifs. París, 1582. 8. ${ }^{\circ}$

Cita, además, un manuscrito que corresponde a una relación de los cautivos que eran criados y oficiales del rey presentada por Juan Gil a Felipe II en 1581. Incluye en el n. 29 a «Miguel de Cervantes, de edad de 31 años, natural de Alcalá de Henares $»^{32}$.

\section{Conclusiones}

Doy por sentado que existió la Relación de 185 cautivos impresa por René Rabut en Granada en 1581 (realidad que, por cierto, nadie ha puesto en duda), conservada hasta su descubrimiento en la Real Biblioteca de Madrid ${ }^{33}$.

Si la relación existió, repugna a la inteligencia pensar que Juan de Iriarte no la conoció, pues la primera noticia que tenemos de su existencia procede de él a través de su sobrino. En el siglo XVIII, tenemos además el testimonio de Pellicer, y en el XX el de García de Armesto. Si Iriarte conoció la Relación, debió comunicarlo a Sarmiento en algún momento entre 1748, año de la llegada de Bernardo a Madrid según su testimonio, y 1761, año en el que Sarmiento redactó su Noticia sobre la verdadera patria (Alcalá) de Él Miguel de Cervantes para impugnar la partida de Alcázar de San Juan. La pregunta que debemos formularnos es por qué ni Sarmiento ni Iriarte dieron noticia del hallazgo de este último. En este punto es preciso señalar diversas cuestiones.

En primer lugar, creo que Sarmiento tenía interés en atribuirse el descubrimiento (al menos dejó buena constancia de ello en sus escritos) y que

32. Y respecto de la polémica sobre la patria de Cervantes, es concluyente lo que Pérez Pastor señala en la página 244, pues aduce el manuscrito de un Pedimento unido al anterior en el que Cervantes, con expresión de su origen, solicita «alguna parte de los maravedíes retenidos en la Casa de Contratación de Sevilla por bienes inciertos de difuntos en Indias».

33. Nada tiene de extraño, pues en la Real Biblioteca aún se conservan documentos relacionados con la redención de cautivos, alguno del siglo XVI. Puede comprobarse fácilmente a través de su catálogo en línea. 
debía pensar, no sin razón, que era obra enteramente suya. Sabemos, además, de su aversión a la vida pública (El porque si y porque no del P. Martín Sarmiento, 1787), que seguramente lo disuadiría de cualquier tentativa de polemizar. Por otra parte, su participación, y la de su colaborador Montiano, se hallaban bien aseguradas.

En segundo lugar, creo que el propio Sarmiento dudaba inicialmente de su intuición, pues en el libro de Haedo solo se expresa que Cervantes era «hidalgo principal de Alcalá», no que hubiera nacido allí (además de que eran varias las localidades que dependían de Alcalá). Por entonces, Mayans había publicado que Cervantes era de Madrid, y, para complicar más las cosas, después (1758) aparecería la partida de Alcázar de San Juan. En la Relación de cautivos, por el contrario, se expresa que Cervantes era natural de Madrid. Este documento permitía relacionar al Cervantes del Quijote con el cautivo en Argel y con el nacido en Alcalá. Además, debe advertirse que una cosa era el descubrimiento (Alcalá) y otra bien distinta su demostración o comprobación documental (Relación de cautivos).

En tercer lugar, no debe soslayarse en absoluto el delicado contexto en el que se produjeron estos hallazgos, incendiado por las polémicas lingüísticoliterarias de la época. A ello hay que añadir los enfrentamientos estrictamente personales y la situación particular de cada uno de los actores. Mayans se había enfrentado con todo el mundo, especialmente con Montiano y Nasarre, próximos a Sarmiento e Iriarte. Don Juan pretendía la plaza de bibliotecario mayor y después obtuvo una pensión real, circunstancias que aconsejaban evitar cualquier polémica. Iriarte era hombre prudente y modesto, y era colaborador de Sarmiento (quizá, y salvando las distancias, en términos aproximados a como lo era Sarmiento de Feijoo) $)^{34}$, y en ese sentido es preciso recordar la particular naturaleza de las relaciones entre los miembros de la República Literaria en la época (ayuda desinteresada). Lo que revela la «carrera» hasta Alcalá es, precisamente, que se produjo el cambio de este modelo por otro basado en la competencia entre los autores, transformación que en don Juan, por su formación y la tradición a la que pertenece, aún no se había producido.

Por lo demás, el progresivo descubrimiento de documentos cervantinos (partidas de bautismo, fe de estado civil, partidas de rescate, partida de defunción) iría restando importancia y oportunidad al hallazgo de don Juan.

En consecuencia, y a tenor de todo lo expuesto, creo que lo más prudente sería considerar que el descubrimiento de la «patria» de Cervantes se debió a ambos eruditos, Sarmiento e Iriarte, y que a ambos corresponde el mérito del hallazgo.

34. Como señala Pérez Rioja (1990), Sarmiento buscaba libros y artículos para Feijoo, para lo cual no era extraño que recurriera a al Real Biblioteca, y aquí entra en juego Iriarte. También comprobaba datos y compulsaba citas y nombres, y, desde 1728, estuvo al cuidado de sus obras y corregía las pruebas de imprenta, además de defender la obra del orensano no solo en la Demonstración apologética, sino en cartas y opúsculos manuscritos. Todo ello con discreción y sin hacer alarde. 


\section{FUENTES}

ABC (1916). «El cultísimo sacerdote D. José García Armesto (...)», Blanco y Negro, 30 04-16, p. 16. Accesible en: <http://hemeroteca.abc.es/nav/Navigate.exe/hemeroteca/ madrid/blanco.y.negro/1916/04/30/016.html>.

ABC, Hemeroteca. Accesible en: <http://hemeroteca.abc.es $>$.

Álvarez de Toledo, Gabriel (1713). Historia de la Iglesia y del Mundo [...]. Madrid: José Rodríguez y Escobar.

Antonio, Nicolás (1788 [1672]). Bibliotheca hispana nova sive hispanorum scriptorum qui ad anno MD ad MDCLXXXIV floruere noticia, auctore D. Nicolao Antonio [...], tomus primus [-secundus]. Matriti: apud Joachim de Ibarra, 1783-1788. [Biblioteca hispana nueva o de los escritores españoles que brillaron desde al año MD hasta el de MDCLXXXIV; 2 vols. y 1 cederrón compartido con la Bibliohteca hispana vetus. Madrid: Fundación Universitaria Española, 1999. Es traducción de la edición hecha por Pérez Bayer entre 1783 y 1788$]$.

Asunción, Antonino de la (1896-1897). «Una redención de Cautivos», Revista Trinitaria. 2, pp. 111-115, 141-144.

Asunción, Domingo de la (1917). «Cervantes y la orden trinitaria: colección de artículos publicados en la revista trinitaria El Santo Trisagio». Madrid: Administración de El Santo Trisagio (hay edición reciente: Londres, Forgotten Books, 2017).

Bacallar y Sanna, Vicente [marqués de San Felipe] (1714). Palacio de Momo: apología joco-seria por la Historia de la Iglesia, y del Mundo [...]. León de Francia (i. e. Madrid): (sin nombre).

Bowle, John (1777). Letter to the Rev. Dr. Percy concerning a new and classical edition of the History del valeroso Cavallero Don Quixote. Londres: B. White.

Bowle, John (1781). «The life of Cervantes», Gentleman's Magazine. 51, pp. 22-24.

Bowle, John (1781). Miguel de Cervantes Saavedra. Historia del famoso cavallero Don Quixote de la Mancha. Londres-Salisbury, 6 t.

Carteret, John (1755) (ed.). Miguel de Cervantes Saavedra. Vida y hechos del ingenioso hidalgo don Quijote de la Mancha. Ámsterdam y Leipzig: por Arkste'e y Merkus, 4 vols.

Cervantes Saavedra, Miguel de (1780). El ingenioso hidalgo don Quixote de la Mancha. Nueva edición corregida por la Real Academia Española. Madrid: Ibarra, 4 t.

Diario de los literatos de España (1737-1742), 7 t. Madrid: Antonio Marín (I), Juan Muñoz (II), Antonio Sanz (III) e Imprenta Real (IV-VII). Existe edición reciente de Jesús Ruiz Veintemilla. Zaragoza: Puvill.

Estala, Pedro (1794). El Pluto, tragedia de Aristófanes traducido del griego [...] con un discurso preliminar [...]. Madrid: Sancha.

Feijoo, Benito (1781). Cartas eruditas y curiosas [...], tomo tercero. Madrid: Blas Román.

Fernández de Navarrete, Martín (1819). Vida de Miguel de Cervantes. Madrid: Real Academia Española, en la Imprenta Real.

Fernández de Navarrete, Martín (2017 [1819]). Vida de Miguel de Cervantes Saavedra (...), reproducción digital de la edición original realizada por la Biblioteca Virtual Miguel de Cervantes. Accesible en: $<$ https://bibliotecafloridablanca.um.es/bibliotecafloridablanca $>$.

Flores y la Barrera, José Miguel de (1764). «Carta escrita sobre la patria de Miguel de Cervantes», Aduana crítica. Vol. III, n. ${ }^{\circ}$ XXVI, pp. 253-282. Madrid: imprenta de D. Gabriel Ramírez.

García de Armesto, José (c. 1916). «Noticia histórica del hallazgo de la "Relación de 185 cautivos (...)"», informe de 4 páginas mecanografiadas dirigido al rey Alfonso XIII conservado en la Real Biblioteca, signatura topográfica: MC/525 (2), pp. 19-22. 
García de la Huerta, Vicente (1785). Theatro hespañol por Don Vicente García de la Huerta [...]. Madrid: Imprenta Real, 15 v.

Haedo, Fr. Diego de (1612). Topographía e historia general de Argel. Valladolid: Diego Fernández de Cardona y Oviedo.

Haedo, Fr. Diego de (1929 [1612]). Topografia e historia general de Argel, edición facsímil de la Sociedad de Bibliófilos Españoles. Madrid, t. I y III.

Huerta y Vega, Francisco Javier Manuel de la (1738). España primitiva: historia de sus reyes y monarcas desde su población hasta Cristo [...]. Madrid: (sin nombre), tomo primero.

Índice (1730). Índice de los libros que contiene la biblioteca de este Real Monasterio de San Martín de Madrid. Ms. disponible en la Biblioteca Digital Hispánica. Accesible en: <http://www.bne.es/es/Catalogos/BibliotecaDigitalHispanica/Inicio/index.html >.

Mayans y Siscar, Gregorio (1737). Orígenes de la lengua española [...]. Madrid: Juan de Zúñiga, 2 t.

Mayans y Siscar, Gregorio (1737). Vida de Miguel de Cervantes Saavedra. [s. 1.: sin nombre].

Mayans y Siscar, Gregorio (1738). The Life of Michael de Cervantes Saavedra. Londres: J. and R. Tonson.

Mayans y Siscar, Gregorio (1738). Vida y hechos del ingenioso hidalgo don Quixote de la Mancha. Londres: J. and R. Tonson.

Mayans y Siscar, Gregorio de (1750). Vida de Miguel de Cervantes Saavedra, natural de Madrid. Madrid: Pedro Joseph Alonso.

Mayans Digital. Gregorio Mayans y Siscar Digital. Biblioteca Valenciana, Biblioteca de Autor. Accesible en: $<$ http://bivaldi.gva.es/es/estaticos/contenido.cmd?pagina=estatico s\%2Fmayans\%2Fma yans_inicio $>$.

Méndez de Silva, Rodrigo (1648). Ascendencia ilustre de [...] Nuño Alfonso [...]. Madrid: Domingo García y Morras.

Montiano y Luyando, Agustín (1750-1753). Discurso sobre la tragedia española. Madrid: José de Orga, 2 tomos.

Mundo, El (1916). «Una relación de cautivos. Don Miguel de Cervantes era de Alcalá de Henares», El Mundo, 23-04-1916, p. 1.

Nasarre, Blas Antonio (ed.) (1749). Comedias y entremeses de Miguel de Cervantes [...]. Madrid: Antonio Marín, tomo I [-II].

Ortiz de Zúñiga, Diego (1677). Anales seculares y eclesiásticos de la [...] ciudad de Sevilla. Madrid: Imprenta Real, Juan Rodríguez Infanzón.

Pellicer y Saforcada, Juan Antonio (1778). «Noticias para la vida de Miguel de Cervantes Saavedra», en Ensayo de una Biblioteca de traductores españoles (...). Madrid: Antonio de Sancha, pp. 143-198.

Perales y Torres, Isidro [pseud. de Blas Nasarre] (1732). Vida y hechos del ingenioso hidalgo Don Quixote de la Mancha [...]. Compuesto por el licenciado Alonso Fernández de Avellaneda. Madrid: Juan Oliveras.

Pérez Pastor, Cristóbal (1897-1902). Documentos cervantinos hasta ahora inéditos [...], 2 v. Madrid: Establecimiento tipográfico de Fortanet.

Porres Alonso, Bonifacio, O. SS. T. (1997). Libertad a los cautivos. Actividad redentora de la orden trinitaria. Tomo I. Redenciones de cautivos (1198-1785). Córdoba-Salamanca: Secretariado Trinitario.

Ríos, Vicente de los (1780). «Pruebas y documentos que justifican la vida de Cervantes», en Real Academia Española (ed.), El Ingenioso hidalgo don Quijote de la Mancha. Madrid: Joaquín Ibarra, t. I, pp. clxv-cc.

[Salazar de Castro, Luis] (1713). Carta del maestro de niños a don Gabriel Álvarez de Toledo. Zaragoza: (sin nombre). 
Sarmiento, Martín (1761). Noticia de la verdadera patria (Alcalá) de El Miguel de Cervantes. Accesible en la Biblioteca Digital Hispánica: <http://www.bne.es>.

Sarmiento, Martín (1767). Catálogo de los Autores de quienes yo Fr. Martín Sarmiento tengo obras. Real Academia de La Historia. Un volumen en $4 .^{\circ}$ Encuadernado en pergamino. Ms. 9-1829.

Sarmiento, Martín (1787 [1758]). El porque si y porque no del P. Martín Sarmiento [...], Antonio Valladares de Sotomayor (ed.), Semanario Erudito. Madrid: Blas Román, t. VI, pp. 121-168.

Sarmiento, Martín (1987 [1761]). Noticia de la verdadera patria (Alcalá) de El Miguel de Cervantes, edición de José Luis Pensado. Santiago: Xunta de Galicia.

Sempere y Guarinos, Juan (1785-1789). Ensayo de una biblioteca española de los mejores escritores del reinado de Carlos III, 6 tomos. Madrid: Imprenta Real (edición facsimilar en 3 volúmenes de la Editorial Gredos, Madrid, 1969. Existe una edición en facsímil digital en la página web de la Biblioteca Virtual Miguel de Cervantes. Accesible en: $<$ http://www.cervantesvirtual.com $>$ ).

Sosa, Antonio de (1990). Diálogo de los mártires de Argel, edición de Emilio Sola y José M. ${ }^{a}$ Parreño. Madrid: Hiperion.

Valladares de Sotomayor, Antonio (ed.) (1789). Martín Sarmiento, «Reflexiones literarias para una biblioteca real y para otras bibliotecas públicas», Semanario Erudito. X-XI, pp. 99-273. Madrid: Blas Román. Hay edición reciente de Santos Puerto (2002), Santiago de Compostela: Consello da cultura galega.

Veranio, Plácido [pseud. De Gregorio Mayans y Siscar] (1737). Conversaciones sobre el Diario de los literatos de España. Madrid: Juan de Zúñiga.

\section{BIBLIOGRAFÍA CITADA}

Aguilar Piñal, Francisco (1983). «Cervantes en el siglo XVIII», Anales Cervantinos. 21, pp. 153-164.

Álvarez, José César (2005). La disputada cuna de Cervantes. Guadalajara: Bornova.

Álvarez, José César (2011). «En un lugar de La Mancha... ¿sí o no?», $A B C$ de Sevilla, 04-04-2011, pp. 69-71. Accesible en: <http://hemeroteca.abc.es>.

Álvarez Faedo, María José (2007). «Lord Carteret y Cervantes: análisis del contexto sociohistórico que propició la primera iniciativa inglesa de editar el Quijote en español y ofrecer una biografía de su autor, en Emilio Martínez Mata (ed.), Cervantes y el "Quijote». Actas del Coloquio Internacional (Oviedo, 27-30 de octubre de 2004). Madrid: Arco, pp. 227-238.

Berbel Rodríguez, José J. (2003). Los orígenes de la tragedia neoclásica española (17371754). La Academia del Buen Gusto. Sevilla: Universidad de Sevilla.

Brandiz, César (2005). Cervantes decodificado. Las raices verdaderas de Cervantes y de Don Quijote y los tópicos que las ocultan. Madrid: Ediciones Martínez Roca.

Canavaggio, Jean (2005). Cervantes, entre vida y creación. Alcalá de Henares: Centro de Estudios Cervantinos.

Cotarelo y Mori, Emilio (2006 [1897]). Iriarte y su época. Tenerife: Artemisa Ediciones.

Cuevas Cervera, Francisco (2009). «Cervantes en el núcleo de los debates estéticos durante el reinado de Carlos IV», en Elena de Lorenzo (coord.), La época de Carlos IV (1788-1808). Actas del IV Congreso Internacional de la Sociedad Española de Estudios del Siglo XVIII. Gijón: Trea, pp. 351-361.

Eisenberg, Daniel (2003 [1996]). "Cervantes, autor de la Topografia e Historia general de Argel publicada por Diego de Haedo», edición de 2003 de la Biblioteca Virtual Cervantes. 
eldiario.es (14/11/2017). «Resucita el debate sobre la cuna de Cervantes por una polémica partida de bautismo». Accesible en: <https://www.eldiario.es/clm/NuevoCervantesAlcazar-San-Juan_0_707979364.html >.

Fernández Valladares, Mercedes (2000-2007). «Una nueva edición del Libro de Albeitería de Francisco de la Reina por fin identificada (Real Biblioteca I/C/211)», en Avisos. Noticias de la Real Biblioteca, 21. Accesible en: $<$ https://avisos.realbiblioteca.es/index. $\mathrm{php} /$ Avisos/article/view/134/90>.

Fraguas, Rafael (2014). «Una cripta alberga 25 sepulturas coetáneas de la de Cervantes», El País, 30-04-2014, p. 37.

González Ollé, Fernando (2014). La Real Academia en su primer siglo. Madrid: Arco.

Ladrón de Guevera e Isasa, Manuel (2011). «La hidalguía. Su origen y evolución. Las reales chancillerías», ASCAGEN, Revista de la Asociación Cántabra de Genealogía. 6, pp. 35-47.

Lizcano Zarceño, Mariano (2006). Miguel de Cervantes - algunas incógnitas sobre su cuna. Casa de Castilla La Mancha en Sevilla. Accesible en: $<$ http://www.cclmsevilla. org/web-antigua/publicaciones.htm>. Fecha de acceso: 29 de mayo de 2019.

Lucía Megías, José Manuel (2016). La juventud de Cervantes. Una vida en construcción. Madrid: Edaf.

Pensado, José Luis (1987). Estudio Preliminar de Noticia de la verdadera patria (Alcalá) de El Miguel de Cervantes. Santiago: Xunta de Galicia.

Perdomo-Batista, Miguel Á. (2011). «El enfrentamiento de Mayans y los Iriarte a propósito de las gramáticas latinas», Cuadernos de Filología Clásica. Estudios Latinos. 31 (2), pp. 355-388.

Perdomo-Batista, Miguel Á. (2012). «Sobre el concepto de Ilustración periférica: el estatuto de lo local en el pensamiento ilustrado español. El ejemplo de Viera y Clavijo», Anuario de Estudios Atlánticos. 58, pp. 215-242.

Perdomo-Batista, Miguel Á. (2017). «La rúbrica del satírico: Tomás de Iriarte y la construcción discursiva del autor», en Elena de Lorenzo (ed.), Ser autor en la España del siglo XVIII. Gijón: Trea, pp. 317-346.

Pérez León, Jorge (2010). «El fraude en la hidalguía: intrusiones en el estado de hijosdalgo durante el siglo XVIII», Estudios Humanísticos. Historia. 9, pp. 121-141.

Pérez Rioja, José Antonio (1990). «Una colaboración bibliográfica singular: la de Martín Sarmiento con Feijoo», El Museo de Pontevedra. 44, pp. 717-729.

Plaza Escudero, Luis (1964). Catálogo de la Colección Cervantina. Volumen V (19161930). Barcelona: Diputación Provincial de Barcelona, Biblioteca Central.

Real Biblioteca, catálogo [en línea]. Accesible en: $<$ https://realbiblioteca.patrimonionacional. es>.

Rey Hazas, Antonio y Juan Ramón Muñoz Sánchez (eds.) (2006). El nacimiento del cervantismo: Cervantes y el Quijote en el siglo XVIII. Madrid: Verbum.

Rodríguez Cepeda, Enrique (1988). «Los Quijotes del siglo XVIII: 1) la imprenta de Manuel Martín», Cervantes. 8 (1), pp. 61-108; y «Los Quijotes del siglo XVIII: 2) la imprenta de Juan Jolis», Hispania. 71 (4), pp. 752-779.

Santos Puerto (ed.) (2002 [1743]). Martín Sarmiento. Reflexiones literarias para una biblioteca real. Santiago de Compostela: Consello da Cultura Galega.

Santos Puerto, José y Elena Santos Vega (2011). «De lo que aconteció cuando Martín Sarmiento se subió a la zebra del moro Muzaraque y encontró a Cervantes en el camino de Alcalá», Anales Cervantinos. 43, pp. 33-51. https://doi.org/10.3989/ anacervantinos.2011.001.

Santos Puerto, José y Elena Santos Vega (2013 [1752]). Martín Sarmiento, Disertación sobre el animal zebra. La Laguna: Universidad de la Laguna. Accesible en: $<$ https:// 
docplayer.es/14334827-Disertacion-sobre-el-animal-zebra.html>. Fecha de acceso: 29 de mayo de 2019.

Ticknor, M. G. (1851-1856). Historia de la literatura española, 4 vols. Madrid: Manuel Rivadeneyra.

Varela-Oriol, Concepción (2016). «Martín Sarmiento y la República Literaria española», Hispania. Vol. LXXVI (254), pp. 693-719.

Vargas Díaz-Toledo, Aurelio (2018). «Un nuevo documento de Antonio de Sosa que prueba ser autor de la Topografía de Argel», X Congreso Internacional de la Asociación de Cervantistas. Madrid: UCM.

Recibido: 23 de septiembre de 2018

Aceptado: 18 de marzo de 2019 